Original Research Paper

\title{
Impact of heat stress on Holstein breeding performance conducted in a semi-arid Mediterranean climate. Case of Western Algeria
}

\author{
Yerou H. ${ }^{2 *}$ Belgherbi B. $^{2}$, Homrani A. ${ }^{3}$ \\ ${ }^{1}$ Department of Agriculture.Faculty natural and live science. University of Mascara 29000. Algeria \\ ${ }^{2}$ Laboratory of Geo-sciences and sustainable development (LGDE). University of Mascara 29000. \\ Algeria \\ 3Department of Animal Science. University of Mostaganem 27000. Algeria
}

*Corresponding Author: YEROU H, University of Mascara, Algeria. Email: : houariyerou@gmail.com

Article history; Received: January 25th 2020 Revised: February 23th 2021 Accepted: March 25th 2021

\begin{abstract}
The dairy cattle husbandry systems in semi arid climate require adapting as a response to climate change. In this study, we focus on semi arid climate of Mediterranean region to assess the effect of heat stress on productive and physiological parameters of Holstein cows. The temperature-humidity index (THI), calculated as a combination of ambient temperature and relative humidity, was used to characterize heat stress. The averages of index (THI) are 71.7, 83.6 and 72.6 respectively for spring; summer and autumn. when the THI increased from average value 12 unit between spring and summer, the cows decreased their daily milk production (DMP) and dry matter intake (DMI) by $17.6 \% \mathrm{~kg} /$ day and $22 \%$ respectevelly.THI value was negatively correlated to DMP with regression equation DMP $(\mathrm{kg} /$ day $)=-0,36 \mathrm{THI}+40.8(\mathrm{r} 2=0.72)$. in semi arid condition a daily increase was observed for RT, RR an HR respectively when the THI value increased from 71.7 to 83.6 (RT $38.6^{\circ} \mathrm{C}$ to $39.1^{\circ} \mathrm{C}$; RR 49.3 inspiration/min to 71.6 inspiration/min and $\mathrm{HR} 52.6 \mathrm{beat} / \mathrm{min}$ to $72.7 \mathrm{beat} / \mathrm{min}$ for spring and summer respectively) with positive correlation between THI and RR, HR and RT. significant seasonal variation was detected for all physiological parameters for spring, summer and autumn period. Summer heat stress affected the physiological functions of lactating Holstein cows reared under semi arid Mediterranean climatic conditions. The Holstein breed cows are sensitive to heat stress in semi arid conditions. In the context of cow breeding practiced in conditions of semi-arid heat stress, it is necessary to find alternatives in terms of management or genetic improvement, in order to alleviate the impact of climatic stress on performance and physiological parameters.

Keywords: Daily milk, physiological parameters, heat stress, Semi arid, Algeria.
\end{abstract}

\section{Introduction}

The impact of climate change has become a pervasive topic in global agricultural production systems, especially for dairy cattle ranching based on exotic breeds introduced into climate-constrained regions. The dairy policy adopted in Algeria led to an orientation of the dairy sector towards imports and for a long time slowed down the development of local dairy farming while promoting the expansion and domination of exogenous dairy breeds. Studies on the evolution of performance in dairy cattle farming have shown that the effect of the environment combined with breeding practices leads to a drop in body weight and the level of milk production. Typological studies indicate the limits of a model based on a large-format exogenous breed, transferred to semi-arid regions to improve milk production (Yerou et al ., 2019). In addition, the results show the need for a debate on the model of dairy farming in arid and semi-arid dairy farms in Mediterranean regions, as well as on the role that the selection of local breeds can have in such conditions. According to Madani and Mouffok (2008), within Algerian semi-arid conditions, insufficient adaptation of introduced dairy breeds was generally put forward as the main explanation for the limited productivity of animals (Boujenane and Aissa, 2008, Bouamra et al. 2019). Indeed, for the same breed, if the breeding conditions are not comparable, the genotypeenvironment interaction takes place and results in differences in the expression of the genotype. Several authors show that production traits and longevity are controlled by separate genes in animals reared in different environments (Carabano et al., 1989, Charagu., 1997, Cromie et al., 1997, Mwansa., 1997) 
The results of dairy performance obtained in Morocco demonstrate the vulnerability of intensive dairy farming in semi-arid zones (Sraïri and Rousse., 2010; Anaflous and Boujenane., 2012; Srairi and Mousili 2014)For Algeria, the average milk production in the semi-arid plains represents on average $9.78 \mathrm{~kg}$ per cow per day (Belhadia and Yakhlef., 2013). Under the current threats of climate change, the relationship of dairy farming to climate is of great importance in climate change risk assessment studies. In Mediterranean dairy production systems, heat stress is indeed one of the most important threats which will unfortunately show an increase according to climate change projections (Iglesias et al., 2011). To assess the impact of heat stress on dairy cows, the Temperature Humidity Index (THI) is widely used in hot areas around the world. The THI is a practical tool for estimating the efficiency response of livestock depending on climate (Ravagnolo et al. 2000; Hahn et al. 2003; Silva et al. 2007; Dikmen and Hansen 2009; Marai and Habeeb 2010). It is based on air temperature and relative humidity with different weights for different species (Hahn et al. 2009). Research in dairy farming has shown that increasing temperatures lead to decreased voluntary feed intake, weight, fertility and milk production (Armstrong 1994; Frank et al. 2001; Kadzere et al. 2002; Amundson et al. 2006; Ben Salem and Bouraoui 2009; Hernández et al. 2011; Gantner et al. 2012; Cicero et al. 2018). According to, Du Preez et al. (1990), milk production is not affected by heat stress when the average THI values are between 35 and 72 .

Under Mediterranean climatic conditions, summer heat stress has considerably reduced the yield and composition of milk. (fat and protein content) in lactating dairy cows. According to Bouraoui et al (2002), increasing THI values from 68 to 78 led to a decrease in DMI of the order of $1.73 \mathrm{~kg}$ and milk production of $4 \mathrm{~kg}$. Thus, the correlation obtained indicates a decrease in milk yield of $0.41 \mathrm{~kg}$ per cow per day for each point of increase in the value of THI above 69.As reported by many authors (Ben Salem et Bouraoui. 2009 ; Rajjeb et al. 2016), ambient temperature and relative humidity are the most well-known factors that significantly affect the milk yield of dairy cattle. Heat stress can reduce food intake, weight gain, reproductive efficiency and milk production, while increasing susceptibility to disease (Kazdere et al., 2002; West, 2003; Hansen, 2007; Dikmen and Hansen, 2009). The ideal temperature for lactating cattle is between 15 and $24{ }^{\circ} \mathrm{C}$ (Frazzi et al. 2003, Allen et al. 2003). In addition, Ravagnolo et al. (2000) indicated an antagonistic effect between cow productivity and heat tolerance implying a deterioration of the effect of selection on productivity and cow's resistance to heat stress. Breeding for heat resistance in breeding strategies would certainly reduce the loss of income in dairy barns and allow for the sustainability of dairy farming. The objective of this research is to assess the relation between heat stress and performance in barns raising Holstein cows in semiarid Algerian conditions and to guide breeders of this breed towards the choice of a mitigation strategy as well as the harmful effects of heat stress and to proceed in the future to a selection of locally calved heifers.

\section{Materials and methods}

The aim of research was to evaluate the impact of THI on Holstein breeding performance in a semiarid climate. This study was carried out in 2020, on 40 Holstein cows fully lactating which were monitored in spring conditions (lack of thermal stress) from March to May 2020; and summer (survival of thermal stress) from June to August, and followed by a period of recession of thermal stress during autumn (September to November) . Cows were chosen according to their level of production $(20.6 \pm 3 \mathrm{~kg})$, lactation stage $(147 \pm 10$ days $)$, lactation number $(3.75 \pm 0.76)$ and live weight $(570 \pm 35 \mathrm{Kg})$. The experiment was carried out during 3 seasons (spring, summer and autumn 2020). The performance monitored are represented by daily milk production (DMP), dry matter intake (DMI), rectal temperature (RT), heart rates (HR) and respiratory rates (RR)

\section{Cows, feeding and management}

Experiment was conducted at a private dairy farm located in Ghriss plain (Western Algeria) which is situated at $35^{\circ} 19^{\prime} 47^{\prime \prime} \mathrm{N}$ et $0^{\circ} 6^{\prime} 49^{\prime \prime}$, receives on average $393.2 \mathrm{~mm} /$ year with semi arid climate type Csa according to classification of Köppen-Geiger. The Feed Management System and Herd Management Strategy were similar for the entire sample of cows chosen. The forage calendar shows a use of green fodder during a large part of the year, (Figure 1). Forage and concentrate were separately provided to the cows to allow for the measurement of individual refusals. Drinking water was provided ad libitum. 
To determine daily DMI, amounts of the feed offered and refused were recorded daily throughout the experiments. Feed leftover was removed and weighed daily prior to the morning feeding.

The cows were milked twice a day (5:00 and 17:00 h) and milk yield of the individual cows was recorded at each milking on all test days. Ambient temperature Ta, RH, RT, and HR were recorded daily. RT was measured by inserting a veterinary digital thermometer into the rectum for approximately $1 \mathrm{~min}$ and the temperatures were recorded to one decimal point. HR was determined using a stethoscope for one minute. RR was measured by counting the flank movements of the individual cows for a period of 1 minute uninterrupted breathing and reported as the number of

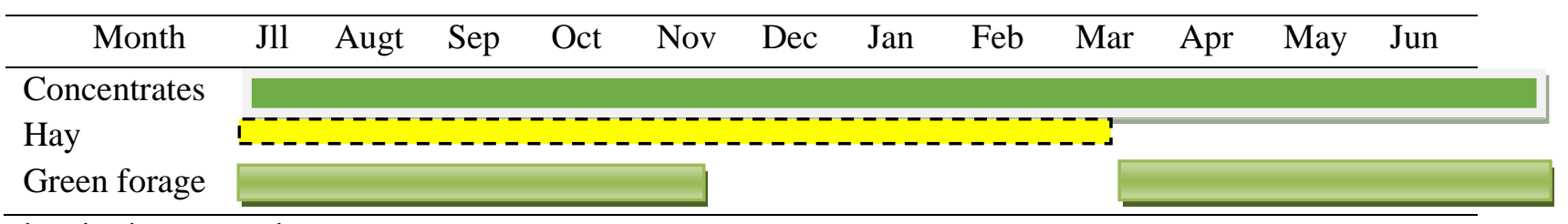

inspirations per minute.

Figure 1. Forage calendar of dairy farms in study region

Weather data was collected from the station located in the region. Data collected included average, minimum and maximum monthly temperatures and relative humidity. The THI index was calculated using the formula described by Johnson et al. (1962) as follows: THI $=1.8 * \mathrm{Ta}-(1-\mathrm{HR}) *(\mathrm{Ta}-$ 14.3 +32 . Where: $\mathrm{Ta}=$ Mean monthly ambient temperature in ${ }^{\circ} \mathrm{C} ; \mathrm{HR}=$ Mean monthly Relative Humidity. Determined THI values were used to identify heat stress seasons and to examine the monthly variation of THI. The classification reported by Du Preez et al. (1990) was adopted to quantify the intensity of heat stress.

Statistical analyze.

A descriptive analysis was performed for the evaluation of averages, standard deviations, minimum and maximum values of the various parameters sutdied. Then a factorial analysis of variance was applied to the results according to the model: Yij $=\square \square+\square \square \mathrm{i}+\mathrm{ei} \mathrm{j}$; Where Yij is the explained variable; $\square$ : the general average, $\square \square \mathrm{i}$ : the factor effect and eij: the residual error of the model. A regression equation was developed between all parameters and THI.

\section{Results and discussion}

\section{Characterization of Microclimatic conditions}

The average evolution of ambient temperature (Ta), relative humidity (RH) and temperature-humidity index (THI) noted in semi arid Mediterranean region is reported in table 1.

Table 1. Average microclimatic conditions according to seasons conditions.

\begin{tabular}{lccc}
\hline Parameter & Spring & Seasons Summer & Autumn \\
\hline Average temperature $\left({ }^{\circ} \mathrm{C}\right)$ & $16.6 \pm 3.21$ & $28.7 \pm 5.68$ & $18,3 \pm 3,62$ \\
Relative humidity $(\%)$ & $58.6 \pm 10.85$ & $45.2 \pm 10.26$ & $61,8 \pm 12,23$ \\
Average daily THI & $71.76 \pm 12.78$ & $83.60 \pm 11.25$ & $72,6 \pm 12,31$ \\
Number of days THI $>72$ & 3 & 16 & 2 \\
\hline
\end{tabular}

As illustrated in Table 1 during spring season which is the period from March to May, average Ta and RH and THI were $16.6 \pm 3.21 \mathrm{oC} ; 58.6 \pm 10.85 \%$ and $71.76 \pm 12.78$ respectively. In summer season (June to August) average values of Ta, RH and THI were $28.7 \pm 5.68 \mathrm{oC}, 45.2 \pm 10.26 \%$ and $83.60 \pm 11.25$ respectively. Average daily THI values indicate variation below the critical heat stress threshold during spring and winter seasons (THI value significantly lower than the critical value. Ambient conditions indicated that Holstein cows were subjected to heat stress conditions, Ta was higher than the critical threshold of $25-26{ }^{\circ} \mathrm{C}$ that is considered a threshold above which zootechnical and physiological parameters are affected. Similar remarks have been made by other authors (e.g. Youssef 1985; Kadzere et al. 2002, Bakir and Kaygisiz., 2013). In their research inside Mediterranean climatic conditions Bellagi et al (2017), report that environmental conditions were high and sufficient to 
stimulate thermal stress betwen June to September. Under the climatic conditions of Tunisia, Bouraoui et al. (2002) indicated reducing of milk yield and DMI when THI was over 68 in lactating Holstein cows. Though, (Ravagnolo et al. 2000; Thatcher et al. 2010) distinct THI $=72$ as the upper critical value above which production traits began to change.

The thermal comfort and stress zones based on THI value varies among different researches (Dash et al., 2016, Polsky and von Keyserlingk, 2017). Moreover, five THI zones are usually used to quantify effect of heat stress in dairy animal (Armstrong, 1994). The THI zones are < 71 (thermal comfort zone), 72-79 (mild heat stress), 80-89 (moderate heat stress), 89-98 (severe heat stress) and death of cows beyond the THI value of 98 (Armstrong, 1994). Analysis of climatic data indicates that Holstein cows raised in semi arid conditions are exposed to heat stress during the period from May to August, characterized by THI values exceeding the critical threshold of 72 (Johnson ,1985). On the other hand, the period from mid-September to December is not characterized by thermal stress (THI) as values do not exceed the critical threshold of 72. According to Armstrong's classification, (1994), it can be deduced that exotic Holstein cows are influenced by mild heat stress in June, moderate heat stress in July and severe heat stress August and mid September. Much of the stress observed is due to the high temperatures combined with relative humidity recorded during summer season which exceeds the upper critical temperature of thermal neutrality for imported breeds of cattle. Variation of heat stress is a function of the seasons, reflecting essentially moderate to severe heat stress which affects the zootechnical parameters of cows. According to Bensalem and Bouraoui, (2009) and Bouraoui and al (2002) variations observed in performance of Holstein breed remain limited to the seasonal variations commonly observed in dairy farms around the world. In arid Saharan conditions of Algeria, Ouarfli and Chehma, (2018) recorded values higher than ours, mainly due to the aridity of this environment. In order to alleviate this heat stress, the adjustment of the feeding behavior of the herd and the control of environmental factors in the barns will remarkably reduce the negative effects of ambient conditions. The thermal comfort zone for temperate-region adult cattle is in the range from 5 to $15 \mathrm{oC}$ as proposed by Hahn et al. (2003). McDowell (1972) revealed that significant changes in feed intake and physiological processes occur with temperatures greater than $25 \mathrm{oC}$. The upper critical temperature for cows is 25 to 26 oC (Bonmanova et al, 2007); cows decrease milk production when THI exceeds the critical comfort zone of 72. In Algeria, the technical and economic results of the dairy performance of dairy farms are weak despite the existence of an improved breed of livestock imported from abroad (Yerou et al.,2019). Exotic breed of cows like Holstein are universally classified as high yielding, in a semi-arid Algerian environment, they produce below their expected levels of performance during lactation in their country of origin (Kaouche et al. 2015 and Yerou et al, 2019). The comparison of the zootechnical performances of breeds introduced in different climatic conditions with the references of exotic breeds in their native cradles reflects an insufficient adaptation of dairy breeds transferred to Mediterranean farming conditions is generally put forward as the main explanation for the limited productivity of animals (Bourbouze and al 1989, Flamant., 1991). Indeed, for the same breed, if the breeding conditions are not comparable, the genotype - environment interaction takes place and results in differences in the expression of the genotype. Several authors show that both production (e.g. Charagu, 1997; Mwansa, 1997) traits are controlled by distinct genes in animals raised in different environments. Therefore, the comparison of the genetic correlation between performances and their heritability's shows a decrease in relation to the increase breeding conditions. Flamant (1991) reports that the effect of climatic stress due to the change of the original environment (such as the case of the transfer of selected animals in temperate environment to Mediterranean countries), whose performances are low compared to the standard of these cows. The exploitation of dairy breeds in environments with strong constraints, as is the case of European breeds in the high semi-arid plains of eastern Algeria, could have consequences on the size of the animals, reproductive performance and milk production, and exhibit long-term effects on successive generations born and managed locally (Toufik and Madani, 2008).

\section{Effects of heat stress on zootechnical parameters}

In the livestock industry, heat stress is a major constraint to the efficient production of animal proteins and to food security (Baumgard and Rhoads, 2013), causing economic burdens for producers and raising serious welfare problems-for animals (St-Pierre et al., 2003; Rhoads et al., 2013). This 
observation is valid for dairy farming systems in the semi-arid Algerian zone (Yerou and al, 2019). On the other hand, dairy animals display maximum genetic potential only in their thermoneutral zone, and a thermal challenge above the upper critical temperature of an animal significantly alters zootechnical and physiological parameters. According to Smith et al. (2013), selecting the most suitable cattle for heat stress tolerance requires an examination of the differences between the dairy breeds. There are several factors like humidity, air speed, genotype of animal; physiological stage as well as acclimation and diet affect the upper limit of thermal comfort zone of dairy cattle (Conte et al., 2018).

The results (Table 2) indicate evolution of heat stress effect on dry matter intake (DMI), Daily milk production (DMP) and physiological parameters (TR $\left({ }^{\circ} \mathrm{C}\right), \mathrm{HR}$ (Bat / $\left.\mathrm{min}\right)$ and RR (Insp./min).

In semi arid conditions of west Algeria, heat stress reduced daily milk yield of Holstein breed by 17.6 $\%$ as the THI values change from 71.7 in spring to 83.6 in summer season with reduction of intake (DMI) by $22 \%$. The same trend was reported with milk yields decline of $21 \%$ when the THI increased from 68 to 78 during the summer period in Tunisian Mediterranean conditions (Bouraoui et al., 2002), for Rajjeb et al (2016) the increase in THI values from 65.6 to 83.2, leads to a decrease in DMI from $2.31 \mathrm{~kg}$ and milk production to $5.59 \mathrm{~kg}$. In addition, West, (1994) indicates that the effect of heat stress is increased for high yielding Holstein cows due to their more intense metabolic activity. for Rajjeb et al (2016) while THI values increased from 65.6 to 83.2, DMI decreased by $2.31 \mathrm{~kg}$, and milk production decreased by $5.59 \mathrm{~kg}$. Also, West, (1994) indicate that the effect of heat stress is increased for high-producing cows such as Holsteins due to their more intense metabolic activity.

Present results indicate that milk yield declined for a THI higher than 72 in June, July and August month. These results are in agreement with those reported by Johnson et al. (1980), Mallonee et al. (1985), Du Preez et al. (1990) and Bakir and Kaygisiz A.,(2013). On the other hand, in the context of global warming, heat stress is one of the major issues that can dramatically affect milk production in areas with a Mediterranean climate, emphasizing the importance of selecting more heat-tolerant dairy cattle breeds (Bellargi and al., 2017). According to Hammami et al. (2013) intensive selection for high yields over fitness traits such as heat tolerance can generally explain the high sensitivity of Holsteins to heat stress. While, Kadzere et al. (2002) indicated a negative effect of hot climates in reducing dry matter intake (DMI) of dairy cows by up to $40 \%$ when the temperature exceeds $30{ }^{\circ} \mathrm{C}$, which led to a reduction of energy balance and a decrease in milk yield. In dairy cattle DMI reduced by $9-13 \%$ in higher ambient temperatures of about 35 oC (Ghosh and al., 2017). It has been reported that DMI reduced by $0.85 \mathrm{~kg}$ for every $1 \mathrm{oC}$ increase in ambient temperature above the upper threshold limit of thermo-neutral zone (West, 2003). Heat stress generally leads to a decrease in voluntary intake, in relation to thermoregulation, to allow a decrease in heat production, especially due to rumen fermentations. In a study on Ingestion and digestion in ruminants subjected to stress, Morand-Fehr and Doreau., (2001) reported that heat stress generally leads to a decrease in voluntary intake, in relation to thermoregulation, to allow a decrease in heat production, in particular due to rumen fermentation. The decrease in intake may also be due to a low availability of fodder on the rangelands, as well as its low nutritional value and problems of drinkable water availability.

Table 2. Variation of zootechnical and physiological parameters

\begin{tabular}{lcccc}
\hline Parameters & Spring & Seasons Summer & Autumn & P value \\
\hline Average daily THI & $71.76 \pm 12.78$ & $83.60 \pm 11.25$ & $72,6 \pm 12,31$ & \\
DMI $(\mathrm{kg} / \mathrm{d})$ & $16.2 \pm 2.85$ & $12.6 \pm 2.64$ & $13.8 \pm 2,72$ & $\mathrm{P}<0.05$ \\
DMP $(\mathrm{kg} \cdot \mathrm{d}-1)$ & $17.6 \pm 2.97$ & $13.8 \pm 3.24$ & $12.8 \pm 2,23$ & $\mathrm{P}<0.01$ \\
TR $\left({ }^{\circ} \mathrm{C}\right)$ & $38.6 \pm 7,8$ & $39.1 \pm 8.9$ & $38.5 \pm 7.27$ & $\mathrm{P}<0.05$ \\
HR $($ Bat $/ \mathrm{min})$ & $52,6 \pm 9.7$ & $72,7 \pm 13.2$ & $50,86 \pm 8.9$ & $\mathrm{P}<0.05$ \\
RR $($ Insp./min & $49,3 \pm 8.1$ & $71,6 \pm 11.4$ & $51,6 \pm 8.4$ & $\mathrm{P}<0.05$ \\
\hline
\end{tabular}

The correlations between THI and DMP in semi arid condition shown in figure 2 indicate a negative relation with expressed by the equation DMP $(\mathrm{kg} /$ day $)=-0,360 \mathrm{THI}+40.86(\mathrm{R} 2=0.72)$. This regression indicates that, in general, for each point increase in the THI value above 65 , there was a decrease in milk yield by $0.36 \mathrm{~kg}$ per cow per day. The value of this relationship for predictive purposes is relatively high, as depicted by coefficient of correlation $(\mathrm{r}=0.85)$. A large part of the variation in DMP can consequently be attributed to heat stress. The decline in milk yield under heat 
stress conditions has also been highlighted in earlier studies, confirming that the exposure of dairy cows to high values of THI causes a reduction of 10 to 34\% in milk yield (Du Preez et al. 1990; Itoh et al. 1998). However, Smith et al. (2013) found that when THI exceeds 72, Holstein milk yield decreased from 35.6 to $34.2 \mathrm{~kg} /$ day $(-3.9 \%)$. Other studies indicate that heat stress negatively affects the milk yield of dairy cattle $\mathrm{r}=-0.66$, (Sirohi and Michaelowa, 2007). Recently, Santana et al. (2015) reported a reduction of milk yield by $0.019 \mathrm{~kg} /$ year in Brazilian Gir breed due to heat stress. As a result reduction of DMI and water may limit the milk secretion in heat stressed cattle. Furthermore, Das et al., (2016) observed that energy required for maintenance cattle also augmented by $30 \%$. For this reason, less energy or nutrient is diverted for milk production. Effect of heat stress is more aggravated in high yielding cattle than the low to moderate yielding cattle due to positive association of milk yield and heat production (Polsky and von Keyserlingk, 2017).

As well, Tao et al (2017) indicate stress reduce milk yield and results in a significant economic loss for the dairy industry. During lactation, heat stress lowers milk production by 25 to $40 \%$ with half of the decrease in milk synthesis resulting from the reduced feed intake.

Another explanation for the DMI reduction is related to the concentrate / forage ratio, in this research the forage share exceeded 64\% therefore energy is generally the most limiting nutrient and a common approach to increasing energy density is to reduce forage and increase the concentrate content of the ration. In addition, the phenomenon of digestion and metabolism generates additional sources of heat production by the cow. According to Coppock and West (1986) rations rich in crude fiber can increase heat production, the results of which show that for rations of 100,75 or $50 \%$ hay, their efficiency in converting metabolizable energy into milk is of 54,61 and 65\%, respectively. As reported by Reynolds et al. (1991), a diet containing $75 \%$ alfalfa resulted in a greater heat production and reduced energy retention compared with a diet containing $75 \%$ concentrate

\section{Effects of heat stress on physiological parameters}

Change in heart rate (HR), respiration rate (RR), and rectal temperature (RT) are the key parameters that indicate the mechanism of physiological adaptation in ruminants. Rectal temperature is a good index of body temperature even though there is a considerable variation in several parts of the body score at different times of the day. In heat-stressed environments, RR is the first thermoregulation mechanism used to help them maintain their body temperature. The complexity and consequent physiological changes due to heat stress response can differ from one animal to another and from individual to another. When animals exposed to the high ambient temperature superior than the critical point, the respiration rate, pulse rate, and rectal temperature increase.

The rectal temperatures measured during monitoring seasons vary from $38.6 ; 39.1$ and $38.5{ }^{\circ} \mathrm{C}$ for spring, summer and autumn respectively. This can be explained by strong correlation between THI and rectal temperature, in fact, an increase in ambient temperature causes an increase in rectal temperature in Holstein dairy cows. Bewley et al., (2008) stated that rectal temperature is directly affected by the ambient temperature and when the ambient temperature rises the rectal temperature will increase as well. For Smith and Risco, (2005) other factors that also affects the rectal temperature are the housing system, how frequently the cows are milked and milking system used. Bewley et al. (2008) mentioned that rectal temperature is directly affected by the ambient temperature and will increase in warmer weather. They also concluded that the rectal temperature is affected by the depth and duration of the probe inserted, and the presence of air or feces in the rectum. Seasonal variation significantly was detected for all physiological parameters,

RT increased from spring $(\mathrm{THI}=71.76)$ with $38.6^{\circ} \mathrm{C}$ to summer $(\mathrm{THI}=83.60)$ with $39.1^{\circ} \mathrm{C}$. Respiratory rates augmented from 49.3Insp./min to 71,6 Insp./min for spring and summer respectively. Heart rates increased from 52,6Beat/min to 72,7 Beat./min. indiacting that cows restore their thermal balance using adaptive mechanisms. In hot season physiological parameters rise per increase of THI unit. A similar trend was confirmed in Holstein breed by Bouraoui et al. (2002); Srikandakumar and Johnson (2004), Cincović et al. (2011); Rejjeb et al (2016) and Ouarfli and Chehma, (2018). According to Benyounes et al (2011), heat stress conditions for cows evoke thermal regulatory reactions in order to try to maintain heat balance. These reactions include increased RR and HR, reduced DMI increased Milk yield via increased body temperature. According to West, (1999) milk 
production decreases when rectal temperature exceeds $38.9{ }^{\circ} \mathrm{C}$. For each increase of $0.55^{\circ} \mathrm{C}$, milk performance and dry matter intake decrease by $1.8 \mathrm{~kg}$ and $1.4 \mathrm{~kg}$, respectively. In semi arid condition a daily increase of 0.3 o $\mathrm{C}, 7$ beats and 4 inspirations per min was observed for RT, HR an RR respectively when the THI value increased from 71 to 83 . Such response changes are adaptive mechanisms initiated by the cow in a challenge to buffer its thermal balance. The RR and HR of Holsteins cows during the spring and summer periods were significantly different. A difference about 0.2 points compared to our study was signaled by Bouraoui et al (2002

Correlations between THI values and increase in each of rectal temperature and respiration rate and decrease in milk yield in heat stressed cattle as THI values increased, the rectal temperatures of cows increased $\left(\mathrm{P}<0.0001, \mathrm{r}^{2}=0.2691\right)$; RT $=0.0587 \mathrm{THI}+34.8$ Collier and al (2011). The study of six heat stress indices based on their correlation with rectal temperatures in Holstein and Jersey dairy cows in a tropical environment does not indicate any correlation between rectal temperature and THI (Silva et al., 2007). Under tropical climate of Puerto Rico, Holstein rectal temperature and respiratory rate was significantly higher (Hernandez et al., 2002) and also mentioned that Holstein performance in tropics in terms of production and tolerance was lowest.

In general According to Collier et al, (2017), producers and consumers are increasingly concerned about the welfare of food animals, and producers know that stressing animals reduces the profitability of their operations. Thus, there will be growing interest in identifying and reducing stressors on dairy farms. Key to continued progress in managing stress on farms will lie in the identification of improved measures of stress that can be applied under practical farming conditions

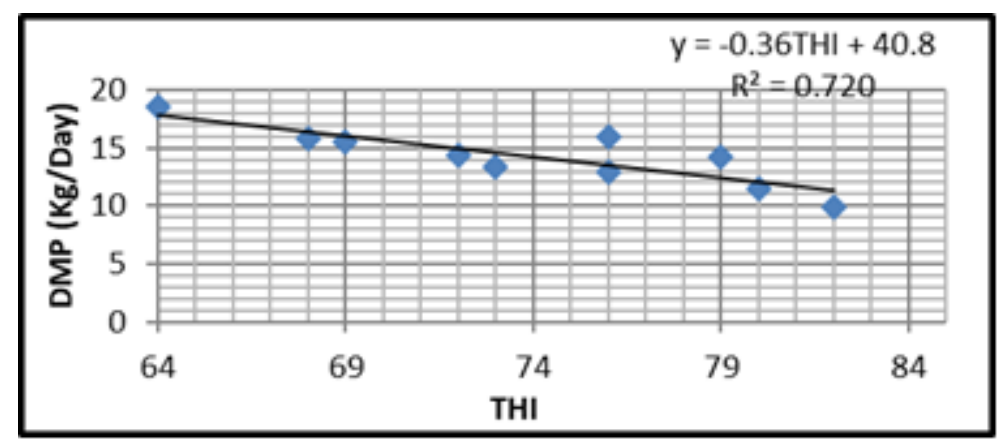

Figure 2. Correlation between THI and daily Milk production

\section{Conclusion}

For underdeveloped countries, the selection of dairy herds for better adaptation to the climateconstrained environment requires the choice of breeds and genotypes that best meet the breeding context in the environment where they are located. The experience of breeding exotic breeds imported into semi-arid and arid areas of Algeria indicates that there are frequent disparities between the environment in which the parents are selected (atmosphere, conduct and management of the breeding) and that where their progenies are exploited. Climate change is an essential factor to be considered to ensure the sustainability of dairy farming (intensive and semi-intensive) in the southern Mediterranean countries. Under the current threats of climate change, the relationship of dairy farming to climate is of great importance in climate change risk assessment studies. Within Mediterranean dairy production systems, heat stress is indeed one of the most important threats which will unfortunately express an aggravation according to climate change projections. Climate change makes it necessary to adapt dairy cows to abiotic stresses (heat, humidity, wind).

In general, the thermal stress that Holstein dairy cows undergo in semi-arid zone, particularly in the summer period when the THI are greater than 80 in the majority of the time with an extension which can occur at 3 months of the year, acts negatively on zootechnical and physiological parameters. Summer heat stress significantly decreased milk yield and dry matter intake in lactating dairy cows managed under semi arid climate. As the THI values increased from 71.7 to, 83.6, DMI decreased by $22 \%$ and milk production by $17.6 \%$.The regression equation obtained under the conditions of the 
present work indicates that milk yield drops by $0.36 \mathrm{~kg}$ per cow per day for each point increase in the value of THI above 71.7. The physiological responses adopted by dairy cows during hyperthermia, reveal a lower thermo-tolerance of Holstein, through the high respiratory and heart rates necessary for thermolysis (thermoregulation). Significant seasonal variation was detected for all physiological parameters for spring, summer and autumn period. Finally, to mitigate the effect of climatic constraints in semi-arid regions on dairy cattle, adaptation strategies must be adopted which must affect the control of the thermal environment of dairy cattle as well as the management of these herds, and genetic improvement by selection on the heat-resistant and the crossing between dairy breeds. These measures seem essential for the breeding of strong dairy cattle in this area with a harsh climate

\section{Acknowledgements}

The authors express their gratitude for the technical support engineers and technicians of the agricultural services department of the Mascara region, and the veterinary service as well as the association of breeders and the chamber of agriculture for their support during the realization of the study. We would like to thank the breeders of Mascara plain region for giving us the opportunity to follow the dairy herds in their stables. Without forgetting the great participation of Master 2 "animal production and nutrition" students from the agricultural sciences department - Nature and Life Science Faculty during their practical training

\section{References}

Allen, DM. Linn JG. Janni KA. 2003. Thermal Environmental Effects on Feed Intake in Commercial Dairy Herds. In J. K. (Ed.), Fifth International Dairy Housing Conference, Vol. 701P0203, ASAE, Forth Worth, Texas, USA, 205-212 pp.

Amundson JL. Mader TL. Rasby RJ. Hu QS. 2006 Environmental effects on pregnancy rate in beef cattle. J Anim Sci 84: 3415-3420. https://doi.org/10.2527/jas.2005-611

Armstrong DV 1994 Heat stress interaction with shade and cooling. J Dairy Sci 77:2044-2050

Bakir G. Kaygisiz A. 2013. Milk Yield Characteristics of Holstein Cows and the Effect of Calving Month on Milk Yield KSÜ Doğa Bil. Derg., 16(1), KSU J. Nat. Sci., 16(1), 2013

Bouamra M. Doubbi Bounaoua L. Si Djilali M. Ghozlane F. 2019. Qualité physicochimique du lait de vaches Prim'Holsteins et Montbéliardes dans l'Ouest algérien. Livestock Research for Rural Development Published 1 February 2019.

Baumgard LH. Rhoads RP. 2013. Effects of heat stress on post absorptive metabolism and energetic. Annu. Rev. Anim. Biosci. 1:311-337.

Ben Salem M. Bouraoui R. 2009 Heat stress in Tunisia: effects on dairy cows and potential means of alleviating it. South African J Anim Sci 39:256-259. https://doi.org/10.4314/sajas.v40i5.65351

Ben Younes R. Ayadi M. Najar T. Caccamo M. Schadt I. Ben M'Rad M. 2011. Hormonal (Thyroxin, Cortisol) and Immunological (Leucocytes) Responses to Cistern Size and Heat Stress in Tunisia. Journal of Life Sciences, 5, 257-265

Belhadia MA. and Yakhlef H. 2013. Milk production and reproduction in dairy cattle farms in the semi-arid region: the "haut Cheliff" plains in northern Algeria. Livestock Research for Rural Development 25 (6), 2013.

Bellagi R. Martin B. Chassaing C. Najar T. Pomiès D. 2017. evaluation of heat stress on Tarentaise and Holsteincow performance in the Mediterranean climate. Int. j. Biometeorol.doi 10.1007/s00484-017-1314-4.

Bewley JM. Einstein ME. Grott MW. Schutz MM 2008.Comparison of reticular and rectal core body temperatures in lactating dairy cows. Journal of Dairy Science, vol. 91, pp.4661- 4672.

Bewley JM. Grott MW. Einstein ME.Schutz MM. 2008. Impact of intake water temperatures on reticular temperatures of lactating dairy cows. Journal of Dairy Science, vol. 91, pp. 3880-3887.

Bohmanova J. Misztal I. Cole JB. 2007. Temperature-humidity indices as indicators of milk production losses due to heat stress. J Dairy Sci 90:1947-1956

Anaflous S. et Boujenane I. 2012. effet du pays d'origine sur les performances zootechniques des vaches Holstein Seminaire programmes d'amélioration genetique des bovins et consequences sur les systems d'élevage. 7-8, 2012. IAV Hassen II-Rabt-Maroc. 
Boujenane I. et Aissa H. 2008. Performances de reproduction et de production laitière des vaches de race Holstein et Montbéliarde au Maroc.Revue Élevage et Médecine vétérinaires des Pays tropicaux 61 (3-4) P 191-196.remvt.cirad.fr/_num/2008/REMVT08

Bouraoui R. Lahmar M. Majdoub A. Djemali M. Belyea R. 2002 The relationship of temperaturehumidity index with milk production of dairy cows in a Mediterranean climate. Anim Res 51:479491. https://doi.org/10.1051/animres:2002036

Bourbouze A. Chouchen A. Eddebarh A. Pluvinage J. Yakhlef H. 1989. Analyse comparée de l'effet des politiques laitières sur les structures de production et de collecte dans les pays du Maghreb. Montpellier, France, Ciheam, p. 247-258.Options méditerr., Sér. Sémin. n 6.

Carabano MJ. Van Fleck LD. Wiggans GR. 1989. Estimation of genetic parameters for milk and fat yields of dairy cattle in Spain and the United States. J. dairy Sci., 72: 3013-3022.

Charagu PK. 1997. Economic efficiency of Canadian and New Zealand sires in Canadian and New Zealand dairy herds and its relationship with other traits. PhD Thesis, University of British Colombia, Vancouver, BC, Canada.

Cincović MR. Branislava B Toholj B. Potkonjak A. Milenko S. Branislav L. and Ivan R. 2011. Metabolic acclimation to heat stress in farm housed Holstein cows with different body condition scores. African Journal of Biotechnology Vol. 10(50), pp. 10293-10303, 5 September, 2011 Available online at http://www.academicjournals.org/AJB DOI: 10.5897/AJB11.847

Collier, RJ. Renquis BJ. Xiao Y. 2017. A 100-Year Review: Stress physiology including heat stress. J. Dairy Sci. 100:10367-10380 https://doi.org/10.3168/jds.2017-13676

Collier R J. Zimbelman R B. Rhoads R P. Rhoads M L. Baumgard LH. 2011. A reevaluation of the impact of temperature humidity index (THI) and black globe humidity index (BGHI) on milk production in high producing dairy cows. Western Dairy Management Conference; March 9-11 Reno, NV. 2011; 113-140.

Coppock CE. West JW. 1986. Nutritional adjustment to reduce heat stress in lactating dairy cows. Proc Georgia Nutr Conf Feed Industry; Atlanta. GA USA: Univ. Georgia. p. 19-62.

Cromie AR. Kelleher DL. Gordon FJ. Rath M. 1997. Genotype by environment interaction for milk production traits in Holstein Friesian dairy cattle. In: 47th meeting European Association for Animal Production, Vienna, Austria, 25-28 Aug. 1997, p. 100-114.

Conte G. Ciampolini R. Cassandro M. Lasagna E. Calamari L. Bernabucci U. Abeni F. 2018. Feeding and nutrition management of heat-stressed dairy ruminants, Italian Journal of Animal Science, DOI: 10.1080/1828051X.2017.1404944

Das R. Sailo L. Verma N. Bharti P. Saikia J. 2016. Impact of heat stress on health and performance of dairy animals: A review. Vet. World. 2016; 9: 260-268. doi: 10.14202/vetworld.2016.260-268

Dikmen S. and Hansen JP. 2009. Is the temperature-humidity index the best indicator of heat stress in lactating dairy cows in a subtropical environment? J. Dairy Sci. 92:109-116.

Du Prezz JH. Hattingh PJ. Giesecke WH. Eisenberg BE. 1990 Heat stress in dairy cattle and other livestock under southern African conditions. Monthly temperature-humidity index mean values and their significance in the performance of dairy cattle. Onderstepoort J. Vet. Res. 57, 241-248.

Frank KL. Mader TL. Harrington JA. Hahn GL. 2001 Potential climate change effects on warmseason livestock productions in the Great Plains. Journal series no. 14462, Agric. Res. Div., University of Nebraska, USA.

Frazzi, E. Calamati L. Calegari F. 2003. Assessment of a Thermal Comfort Index to Estimate the Reduction of Milk Production Caused by Heat Stress in Dairy Cow Herds. In J. K. (Ed.). Fifth International Dairy Housing Conference, Vol. 701P0203, ASAE, Forth Worth, Texas, 269276,USA.

Gantner V. Mijić P. Jovanovac S. Raguž N. Bobić T. Kuterovac K. 2012 Influence of temperaturehumidity index (THI) on daily production of dairy cows in Mediterranean region in Croatia. In: Casasús I, Rogošiç J, Rosati A, Štokoviç I, Gabiña D (ed) Animal farming and environmental interactions in the Mediterranean region. European Federation of Animal Sciences (EAAP) scientific series no. 131, Wageningen Academic Publishers, pp 71-78.

Ghosh CP. Kesh SS. Tudu NK. Datta S. 2017. Heat Stress in Dairy Animals - Its Impact and Remedies: A Review, Int. J. Pure App. Biosci. 5(1): 953-965 (2017). doi: http://dx.doi.org/10.18782/2320-7051.2577 
Hahn GL. Mader TL. Eigenberg RA. 2003 Perspective on development of thermal indices for animal studies and management. In: Lacetera N, Bernabucci U, Khalifa HH, Ronchi B, Nardone A (eds) Interaction between climate and animal production. EAAP technical series 7. Wageningen Academic Publishers, The Netherlands, pp 31-44.

Hammami H. Bormann J. M'hamdi N. Montaldo HH. Gengler N. 2013 Evaluation of heat stress effects on production traits and somatic cell score of Holsteins in a temperate environment. J Dairy Sci 96:1844-1855.

Hansen PJ. 2007. Exploitation of Genetic and Physiological Determinants of Embryonic Resistance to Elevated Temperature to Improve Embryonic Survival in Dairy Cattle During Heat Stress. Theriogenology 68:242-249.

Hernández A. Domínguez B Cervantes P. Muñoz-Melgarejo S. Salazar-Lizán S. TejedaMartínez A. 2011. Temperature-humidity index (THI) 1917-2008 and future scenarios of livestock comfort in Veracruz, México. Atmósfera 24:89-102.

Iglesias A. Mougou R. Moneo M. Quiroga S. 2011 Towards adaptation of agriculture to climate change in the Mediterranean. Reg Environ Chang 11(S1):159-166. https://doi.org/10.1007/s10113$010-0187-4$.

Johnson HD. 1980. Environmental management of Cattle to Minimize the Stress of Climate Changes. Int. J. Biometeor. 24 (Suppl. 7, Part 2):65-78.

Kadzere CT. Murphy MR. Silanikove N. Maltz E. 2002. Les températures estivales entraînent un stress thermique qui induit une baisse des performances, surtout chez les vaches hautes productrices comme la Holstein. Livest. Prod. Sci., 77, 59-91

Kaouche AS. Ghozlane F. Mati A. 2015 Typology of dairy farming systems in the Mediterranean basin (case of Algeria). Biotechnology in Animal Husbandry 31 (3), 385-396.

Kina Stientje H. and Žiga M. 2019 Adaptations in irrigated agriculture in the Mediterranean region: an overview and spatial analysis of implemented strategies. Regional Environmental Change (2019) 19:1401-1416 https://doi.org/10.1007/s10113-019-01494-8.

Köppen W. 1884. The thermal zones of the earth according to the duration of hot, moderate and cold periods and to the impact of heat on the organic world. Meteorologische Zeitschrift 20, 351-360.

Madani T. And Mouffok C. 2008. Production laitière et performances de reproduction des vaches Montbéliardes en région semi-aride algérienne. Revue d'Élevage et de Médecine vétérinaire des Pays tropicaux 200861 (2) 97-107.remvt.cirad.fr/cd/derniers_num/2008/EMVT08_097_107.pdf

Mallonee PG. Beede DK. Collier RJ. Wilcox CJ. 1985. Production and Physiological Responses of Dairy Cows to Varying Dietary Potassium During Heat Stress. J. Dairy Sci. 68:1479-1487.

Marai IFM. Habeeb AAM. 2010 Buffalo's biological function as affected by heat stress-a review. J Livestock Sci 127:89-109.

Mohamed ME. And Johnson HD. 1985. Effect of growth hormone on milk yields and related physiological functions of Holstein cows exposed to heat stress, J. Dairy Sci. 68 (1985) 11231133.

Morand-Fehr P. Doreau M. 2001. Ingestion et digestion chez les ruminants soumis à un stress de chaleur. INRA Prod. Anim., 14, 15-27.

Mwansa PB. 1997. Genetic analyses of longevity in Canadian and New Zealand dairy herds.PhD Thesis, University of British Colombia, Vancouver, BC, Canada.

Ouarfli L. and Chehma A. 2018. Index température-humidité et réussite de l'insémination artificielle de vaches laitières Holsteins et Montbéliardes en région saharienne. Livestock Research for Rural Development 30 (10) 2018.

Polsky L. and Von keyserlingk MAG. 2017 Invited review: Effects of heat stress on dairy cattle welfare.J. Dairy Sci. 100:8645-8657 https://doi.org/10.3168/jds.2017-12651

Ravagnolo O. Misztal I. Hoogenboom G. 2000. Genetic component of heat stress in dairy cattle, development of heat index function. J. Dairy Sci. 83:2120-2125.

Rejeb M. Sadraoui R. Najar T. Ben MM. Rejeb M. 2016 A complex interrelationship between rectal temperature and dairy cows' performance under heat stress conditions. Open J Anim Sci 2016;6:24-30. http://dx.doi.org/10.4236/ojas.2016.61004

Reynolds et al.1991. Reynolds CK, Tyrrell HF, Reynolds PJ. 1991. Effects of diet forage-toconcentrate ratio and intake on energy metabolism in growing beef heifers: whole body energy and nitrogen balance and visceral heat production. J Nutr. 121:994-1003. 
Rhoads RP. Baumgard LH. Suagee JK. Sanders SR. 2013. Nutritional interventions to alleviate the negative consequences of heat stress. Adv. Nutr. 4:267-276.

Roeleveld ACW. \& Van Den Broek A. 1996 Focusing livestock systems research. Royal Tropical Institute, Amsterdam. 151p.

Santana JRML. Pereira RJ. Bignardi AB. Vercesi Filho AE. Menéndez-Buxadera A. EL faro L. 2015. Detrimental effect of selection for milk yield on genetic tolerance to heat stress in purebred Zebu cattle: genetic parameters and trends. Journal of Dairy Science, v.98, p.9035- 9043, 2015. DOI: $10.3168 /$ jds.2015-9817

Silva RGD. Morais DAEF. Guilhermino MM. 2007. Evaluation of thermal stress Indices for dairy cows in tropical regions. Revista Brasileira de Zootecnia, 36: 1192-1198.

Sirohi S. and Michaelowa A. 2007 Sufferer and cause: Indian livestock and climate change. Climatic Change (2007) 85:285-298 DOI 10.1007/s10584-007-9241-8

Smith DL. Smith T. Rude BJ. Ward SH. 2013 Short communication: comparison of the effects of heat stress on milk and component yields and somatic cell score in Holstein and Jersey cows. J Dairy Sci 96:3028-3033

Sraïri MT. Mousili N. 2014. Effets de la conduite zootechnique sur les performances de deux élevages bovins laitiers en zone semi-aride au Maroc. Revue " Nature \& Technologie ». BSciences Agronomiques et Biologiques, $\mathrm{n}^{\circ}$ 10/Janvier 2014. Pages 50 à 55

Sraïri MT. et Rousse EH. 2010. Cas d'un élevage laitier intensif en zone pluviale au Maroc : des cultures au cheptel bovin, quelles voies d'amélioration ?. Fourrages 201, p. 61-65.

Srikandakumar A. EH. Johnson. 2004. Effect of heat stress on milk production, rectal temperature, respiratory rate and blood chemistry in Holstein, Jersey and Australian Milking Zebu cows. Trop. Anim. Health Prod. 36:685-692. https:// doi .org/ 10 .1023/ b: trop .0000042868 .76914 .a9.

St-Pierre NR. Cobanov B. Schnitkey G. 2003. Economic losses from heat stress by US livestock industries. J. Dairy Sci. 86(E Suppl): E52-E77.

Tao S. Orellana S. Weng X. Marins TN. Dahl GE. Bernard JK. 2017. Symposium review: The influences of heat stress on bovine mammary gland function. J. Dairy Sci. 101:5642-5654 https://doi.org/10.3168/jds.2017-13727

Thatcher WW Flamenbaum I. Block J. Bilby TR. 2010 Interrelationships of heat stress and reproduction in lactating dairy cows. In: High plains dairy conference, Amarillo, Texas, pp46-60

West JW. 2003. Effects of heat-stress on production in dairy cattle. J Dairy Sci 86:2131-2144

West J W. 1994 Interactions of energy and bovine somatotropin with heat stress. J Dairy Sci 77:2091-2102.

Yerou H. Homrani A. Benhanassali A. Boussedra D. 2019. Typological assessment of dairy farms systems in semi-arid Mediterranean region of western Algeria. Biotechnology in Animal Husbandry 35 (4), 335-346 , 2019. https://doi.org/10.2298/ BAH1903209K

Yousef MK.1985. Basic principles. Stress physiology in livestock, Vol 1. CRC Press, Boca Raton, FL. 